\title{
Study of Potassium Silicate Spraying in Coffee Plants to Control Oligonychus ilicis (McGregor) (Acari: Tetranychidae)
}

\author{
Melissa Alves de Toledo', Paulo Rebelles Reis ${ }^{2}$ \\ ${ }^{1}$ Postgraduate Program, Universidade Federal de Lavras-UFLA, Lavras, Brazil \\ ${ }^{2}$ Empresa de Pesquisa Agropecuária de Minas Gerais-EPAMIG Sul/EcoCentro, Lavras, Brazil \\ Email: paulo.rebelles@epamig.ufla.br
}

How to cite this paper: de Toledo, M.A. and Reis, P.R. (2018) Study of Potassium Silicate Spraying in Coffee Plants to Control Oligonychus ilicis (McGregor) (Acari: Tetranychidae). Advances in Entomology, 6, 14-26.

https://doi.org/10.4236/ae.2018.61003

Received: November 27, 2017

Accepted: January 22, 2018

Published: January 25, 2018

Copyright $\odot 2018$ by authors and Scientific Research Publishing Inc. This work is licensed under the Creative Commons Attribution International License (CC BY 4.0).

http://creativecommons.org/licenses/by/4.0/

\begin{abstract}
The southern red mite, Oligonychus ilicis (McGregor) (Acari: Tetranychidae) can cause a significant reduction in the photosynthesis potential and the growth of new coffee plants (Coffea spp., Rubiaceae). Studies suggest that the leaf spraying of silicon ( $\mathrm{Si}$ ) leads to increase plants resistance in order to reduce infestations of insect pests such as herbivores, borers, sucking insects and mites. The objective of this study was to evaluate the effect of leaf spraying of potassium silicate $\left(\mathrm{K}_{2} \mathrm{SiO}_{3}\right)$ to control the southern red mite in coffee plants. Experiments were conducted in coffee plants (Coffea arabica L.), grown in a greenhouse, by means of completely randomized design with six treatments: Dose 0 (control), 2, 4, 6, 8 and 10 liters of silicate potassium ha ${ }^{-1}$ and five replications. Plants treated with potassium silicate, regardless of the applied dose, had a lower $O$. ilicis infestation compared to the control, not allowing the population increase, thus a smaller damage in coffee leaves. The silicon content in leaves was higher in plants treated with the highest dose of potassium silicate. It was observed that there was induction of defense molecules such as tannins and lignin in plants sprayed with potassium silicate. It was concluded that the potassium silicate applied in leaf spraying had positive effect on reducing $O$. ilicis attack in coffee plants, even being a dicot. Therefore, the applications of potassium silicate by leaf spraying can be used in programs of integrated management of the southern red mite in coffee, with a view to sustainable management and environmental protection.
\end{abstract}

\section{Keywords}

Induced Resistance, Agricultural Acarology, Silicon, Integrated Pest Management, Potassium Metasilicate 


\section{Introduction}

The southern red mite, Oligonychus ilicis (McGregor) (Acari: Tetranychidae), is an important pest of the coffee plantations (Coffea spp., Rubiaceae) in all producing regions of Brazil. This mite lives in the upper surface of the leaves and pierce the cells of the epidermis and mesophyll for their feeding and absorbs part of the cellular content that overflows [1]. As a consequence, the leaves lose their natural brightness, become tanned, with a reduction of up to $50 \%$ in the potential of photosynthesis [2] and delayed growth of new plants [3], resulting in damage to the development of plants and in coffee production [4] [2]. The continued use of chemical acaricides to control the $O$. ilicis mite population may result in resistant specimens among the mite population, as well as the possibility of causing resistance in other pests of coffee and affecting human health due to high amounts of toxic waste [1] [5] [6] [7].

Studies suggest that the application of silicon ( $\mathrm{Si}$ ) leads to increase resistance of plants in order to prevent the development of pests and diseases and thus enable a more sustainable agriculture [8]. And has been shown to reduce infestations of insect pests such as herbivores, borers, sucking insects, and mites [9] [10] [11].

Positive effects on the use of $\mathrm{Si}$ are evident in the reduction of feeding time of the aphid Schizaphis graminum (Rondani) (Hemiptera: Aphididae) in wheat (Triticum aestivum L., Poaceae) [12], protection of cucumber plant (Cucumis sativa L., Cucurbitaceae), eggplant (Solanum melongena L., Solanaceae), common bean (Phaseolus vulgaris L., Fabaceae) and corn (Zea mays L., Poaceae) against the two-spotted spider mite, Tetranychus urticae Koch (Tetranychidae) [13] and reduced the palatability of sunflower leaves (Helianthus annuus L., Asteraceae) to the attack of caterpillar Chlosyne lacinia saundersii Doubleday (Lepidoptera: Nymphalidae) [14].

The silicon implementation efficiency can also be observed in the third trophic level, as shown in experiment Y-tube olfactometer; cucumber plants (C. sativus) treated with potassium silicate and infested with Helicoverpa armigera Hübner (Lepidoptera: Noctuidae) were more attractive to the predator Dicranolaius bellulus (Guérin-Méneville) (Coleoptera: Melyridae) compared with infested plants with $H$. armigera and without potassium silicate application. Results suggest that $\mathrm{Si}$ applied to plants with subsequent pest infestation increases the plants' attractiveness to natural enemies; an effect that was reflected in elevated biological control in the field [15].

Although, there is a great diversity of studies that prove the importance of silicon as a beneficial element to the diverse cultures, and as inducing agent of resistance to pests, few studies are found in the literature involving the application of silicon in the coffee plantations (Coffea spp.) and the effect on pest mites of this agroecosystem. Therefore, experiments were conducted with the objective of evaluating the attack of $O$. ilicis on coffee plants treated with potassium silicate $\left(\mathrm{K}_{2} \mathrm{SiO}_{3}\right)$, applied by leaf spraying, for a more sustainable management of the pest and environmental protection. 


\section{Material and Methods}

The experiment was carried out in laboratory and greenhouse at the experimental station of Empresa de Pesquisa Agropecuária de Minas Gerais - EPAMIG Sul, in Lavras, Minas Gerais, Brazil.

\subsection{Lab Rearing of the Oligonychus ilicis}

Adults of $O$. ilicis were collected in coffee plantations (Coffea arabica L.) free of agrochemicals, in the municipality of Lavras, state of Minas Gerais, Brazil, and taken to the laboratory of acarology of the EPAMIG Sul/EcoCentro, in Lavras, and reared under controlled temperature conditions at $25^{\circ} \mathrm{C} \pm 2{ }^{\circ} \mathrm{C}, 70 \% \pm 10 \%$ of relative humidity and 14 hours of photophase.

The mites were reared in detached leaves of coffee placed on a sponge with 1 $\mathrm{cm}$ thickness occupying the entire bottom of an uncapped Petri dish $(15 \mathrm{~cm}$ diameter) constantly moistened with distilled water. A strip of hydrophilic cotton was placed around the leaf and in contact with the wet sponge to maintain its turgescence and serve as a physical barrier to prevent the mites from escaping [16] [17].

\subsection{Test of the Topical plus Residual Effect of Si on Coffee Leaves after Leaf Spraying}

Were used 30 coffee plants of the Yellow Catucaí cultivar ( $C$. arabica) with approximately $80-100 \mathrm{~cm}$ of height, planted in pots with 20 liters' capacity.

Forty adult females of $O$. ilicis, from the laboratory rearing, were transferred with the aid of a thin brush for each of the 30 coffee plants.

The treatments analyzed consisted of potassium silicate $\left(\mathrm{K}_{2} \mathrm{SiO}_{3}\right)$ as a silicon source (Si 12.2\% - $171 \mathrm{~g} /$ liter; $\mathrm{K}_{2} \mathrm{O} 12.5 \%$ - $175 \mathrm{~g} /$ liter), from UNA-PROSIL ${ }^{\circledR}$ (Usina Nova América Indústria e Comércio, Paracambi, Rio de Janeiro, Brazil). The doses 2, 4, 6, 8 and 10 liters of potassium silicate $\mathrm{ha}^{-1}$ were tested, applied by leaf spraying mean, and a control (dose 0 ) was sprayed with water alone. The experimental design was completely randomized with six treatments and five replicates.

Two applications of potassium silicate with an interval of 15 days were carried out over the mites on the leaves infested with the pest mites. For the spraying, a manual sprayer of constant pressure was used and then the plants were kept inside a greenhouse.

From 3 and 7 days of the first application and 7 and 15 days from the second application one leaf was removed from each plant and taken to the laboratory, where the numbers of eggs, young stages (larvae and nymphs) and alive adults of the mite $O$. ilicis were counted under a binocular stereoscopic microscope with an increase of up to $40 x$.

\subsection{Test of the Residual Effect of Si on Coffee Leaves after Leaf Spraying}

The methodology of this experiment was similar to that used in the experiment 
of the topical plus residual effect of Si on leaves, differing in infestation by mites, which was carried out at 24 hours and at 15 days after the application of potassium silicate, with the transfer of 40 females of $O$. ilicis, from the rearing laboratory, for each coffee plant, and one application of potassium silicate was carried out before infestation of the leaves with the mites. Evaluations were performed from 7,15 and 21 days of the infestation, in the same manner as in the former experiment.

\subsection{Determination of Silicon Content on Coffee Leaves after Leaf Spraying}

The end of experiment, the plants leaves of the treatments were collected and submitted to an analysis of the Si leaf concentration in the Laboratory of Fertilizer Technology (LAFER) of the Federal University of Uberlândia, MG, Brazil (UFU), using the methodology of Korndörfer, Pereira and Camargo [8].

\subsection{Evaluation Coffee Leaf Damage by Oligonychus ilicis}

The leaf damage of the mite $O$. ilicis, reddish brown marks on the upper surface of the coffee leaves, was evaluated by means of damage index (ID) according to Smith-Meyer [18], and notes from 0 to 5 are assigned, with some modifications: $0=$ absence of damage; $1=$ up to $20 \%$ of the leaf area with damage; $2=21 \%$ $40 \%$ of leaf area with damage; $3=41 \%-60 \%$ of leaf area with damage; $4=61 \%$ $80 \%$ of leaf area with damage and $5=$ more than $80 \%$ of leaf area with damage.

\subsection{Determination of the Tannin and Lignin Contents in Coffee Leaves after Leaf Spraying}

Ten leaves of coffee plants were detached from each pots (replication) of the control and of the treatment 6 (dose 10 liters of potassium silicate/ha, highest dose analyzed) and dried in a drying oven at $60^{\circ} \mathrm{C}$; after being crushed in Willy TE-648 mill with 30 meshes sieve.

The samples were sent to the Laboratory of Vegetable Products of the Department of Food Science of the Federal University of Lavras - UFLA, Lavras, MG, Brazil, for the determination of tannins and lignin. For tannin contents the leaf extract was obtained according to the methodology of Deshpande, Cheryan and Salunke [19] and determination was performed by the Folin-Ciocalteau colorimetric method, according to AOAC [20]. The lignin content was determined by Van Soest method [21].

\subsection{Statistical Analysis}

The obtained data from the number of mites in the leaves were submitted to the normality test of Shapiro-Wilk and presented normality and homogeneity for all evaluated parameters. The values obtained were submitted to analysis of variance and the means number were compared by the Tukey test $(\mathrm{P} \leq 0.05)$ [22]. Greenhouse leaf damage indexes were analyzed using the Kruskal-Wallis test and the means number of treatments were compared with Dunn's test $(\mathrm{p}=$ 
0.05). For the experiment of tannin and lignin the contents were used the Student's t test.

\section{Results}

\subsection{Topical plus Residual Effects of $\mathrm{Si}$ in Coffee Leaves after the Leaf Spraying}

The results show that the number of $O$. ilicis mites, in the immature and adult phases, no significant difference was observed between potassium silicate and control doses in the first two weeks after the first application of the product (Table 1). After 7 days of the second Si application, it was observed that all treatments with silicate presented a reduction in infestation of $O$. ilicis in relation to the control, and the dose of 10 liters/ha of silicate (treatment 6) presented the lowest number of alive $O$. ilicis. After 15 days of the second Si application, the control and treatment 2 (2 liters of silicate/ha) presented a higher number of alive mites than the other treatments (Table 1 ).

The number of eggs placed by $O$. ilicis was affected by the different doses of potassium silicate only after 7 days of the first application, where the control and treatment 3 (4 liters/ha) presented higher number of eggs in relation to the other treatments, in the following evaluations no differences were observed between the analyzed doses (Table 2).

A regression analysis showed that 15 days after the second application of potassium silicate, the higher dose of the applied product show the lower the number of mites (adults, larvae and alive nymphs) (Figure 1) and eggs found in coffee leaves (Figure 2).

\subsection{Residual Effect of Si in Coffee Leaves after the Leaf Spraying}

The potassium silicate residue resulting from leaf spraying, at all doses analyzed, significantly reduced the infestation of mites in immature and adult phases, compared to the control that showed a high $O$. ilicis infestation (Table 3).

Table 1. Number (mean \pm SE) of alive mites (adults, larvae and nymphs) of Oligonychus ilicis, per coffee leaf, as a function of the topical plus residual effect of potassium silicate, after 3 and 7 days of the first application, and 7 and 15 days after the second application.

\begin{tabular}{|c|c|c|c|c|}
\hline \multirow{2}{*}{$\begin{array}{c}\text { Treatments } \\
\text { Liters of potassium } \\
\text { silicate/ha }\end{array}$} & \multicolumn{4}{|c|}{ Number of alive mites per coffee leaf* } \\
\hline & $\begin{array}{l}\text { At } 3 \text { days after the } \\
1^{\text {st }} \text { application }\end{array}$ & $\begin{array}{c}\text { At } 7 \text { days after the } \\
1^{\text {st }} \text { application }\end{array}$ & $\begin{array}{l}\text { At } 7 \text { days after the } \\
2^{\text {nd }} \text { application }\end{array}$ & $\begin{array}{l}\text { At } 15 \text { days after } \\
\text { the } 2^{\text {nd }} \text { application }\end{array}$ \\
\hline 1. Control & $29.20 \pm 20.61 \mathrm{a}$ & $11.40 \pm 10.55 \mathrm{a}$ & $60.20 \pm 19.60 \mathrm{a}$ & $49.40 \pm 42.55 \mathrm{a}$ \\
\hline 2. 2 liters & $23.00 \pm 24.09 \mathrm{a}$ & $0.80 \pm 01.79 \mathrm{a}$ & $10.00 \pm 08.00 \mathrm{~b}$ & $17.80 \pm 20.62 \mathrm{ab}$ \\
\hline 3. 4 liters & $2.40 \pm 01.14 \mathrm{a}$ & $7.20 \pm 05.67 \mathrm{a}$ & $37.60 \pm 24.70 \mathrm{ab}$ & $05.60 \pm 06.06 b$ \\
\hline 4. 6 liters & $2.80 \pm 02.59 \mathrm{a}$ & $1.00 \pm 00.70 \mathrm{a}$ & $12.20 \pm 09.81 \mathrm{~b}$ & $07.60 \pm 03.91 \mathrm{~b}$ \\
\hline 5. 8 liters & $8.00 \pm 07.97 \mathrm{a}$ & $5.80 \pm 08.01 \mathrm{a}$ & $23.00 \pm 26.57 \mathrm{~b}$ & $07.80 \pm 05.58 \mathrm{~b}$ \\
\hline 6. 10 liters & $3.20 \pm 04.15 \mathrm{a}$ & $0.60 \pm 00.55 a$ & $05.00 \pm 05.19 b$ & $02.60 \pm 02.60 \mathrm{~b}$ \\
\hline
\end{tabular}

${ }^{\star}$ Means followed by the same letter in the column do not differ by Tukey's test $(\mathrm{P} \leq 0.05)$. 
Table 2. Number (mean \pm SE) of Oligonychus ilicis eggs per coffee leaf, as a function of the topical plus residual effect of potassium silicate, 3 and 7 days after the first application, and 7 and 15 days after the second application.

\begin{tabular}{ccccc}
\hline \multirow{2}{*}{$\begin{array}{c}\text { Treatments } \\
\text { Liters of potassium } \\
\text { silicate/ha }\end{array}$} & $\begin{array}{c}\text { At } 3 \text { days after } \\
1^{\text {st }} \text { application }\end{array}$ & $\begin{array}{c}\text { At } 7 \text { days after the } \\
1^{\text {st }} \text { application }\end{array}$ & $\begin{array}{c}\text { At } 7 \text { days after the } \\
2^{\text {nd }} \text { application }\end{array}$ & $\begin{array}{c}\text { At } 15 \text { days after the } \\
2^{\text {nd }} \text { application }\end{array}$ \\
\hline 1. Control & $55.60 \pm 39.83 \mathrm{a}$ & $101.00 \pm 19.026 \mathrm{a}$ & $75.80 \pm 71.00 \mathrm{a}$ & $29.00 \pm 17.17 \mathrm{a}$ \\
2. 2 liters & $47.00 \pm 45.22 \mathrm{a}$ & $16.00 \pm 25.05 \mathrm{~b}$ & $40.00 \pm 58.03 \mathrm{a}$ & $40.60 \pm 23.49 \mathrm{a}$ \\
3. 4 liters & $17.40 \pm 20.58 \mathrm{a}$ & $65.80 \pm 40.41 \mathrm{ab}$ & $45.40 \pm 24.60 \mathrm{a}$ & $45.20 \pm 44.61 \mathrm{a}$ \\
4. 6 liters & $16.20 \pm 15.10 \mathrm{a}$ & $18.40 \pm 11.15 \mathrm{~b}$ & $29.80 \pm 12.25 \mathrm{a}$ & $29.20 \pm 28.70 \mathrm{a}$ \\
5. 8 liters & $52.00 \pm 51.69 \mathrm{a}$ & $25.20 \pm 32.57 \mathrm{~b}$ & $30.80 \pm 29.82 \mathrm{a}$ & $29.80 \pm 12.95 \mathrm{a}$ \\
6. 10 liters & $28.60 \pm 34.38 \mathrm{a}$ & $18.20 \pm 11.76 \mathrm{~b}$ & $26.80 \pm 22.87 \mathrm{a}$ & $23.20 \pm 21.79 \mathrm{a}$ \\
\hline
\end{tabular}

${ }^{*}$ Means followed by the same letter in the column do not differ by Tukey's test $(\mathrm{P} \leq 0.05)$.

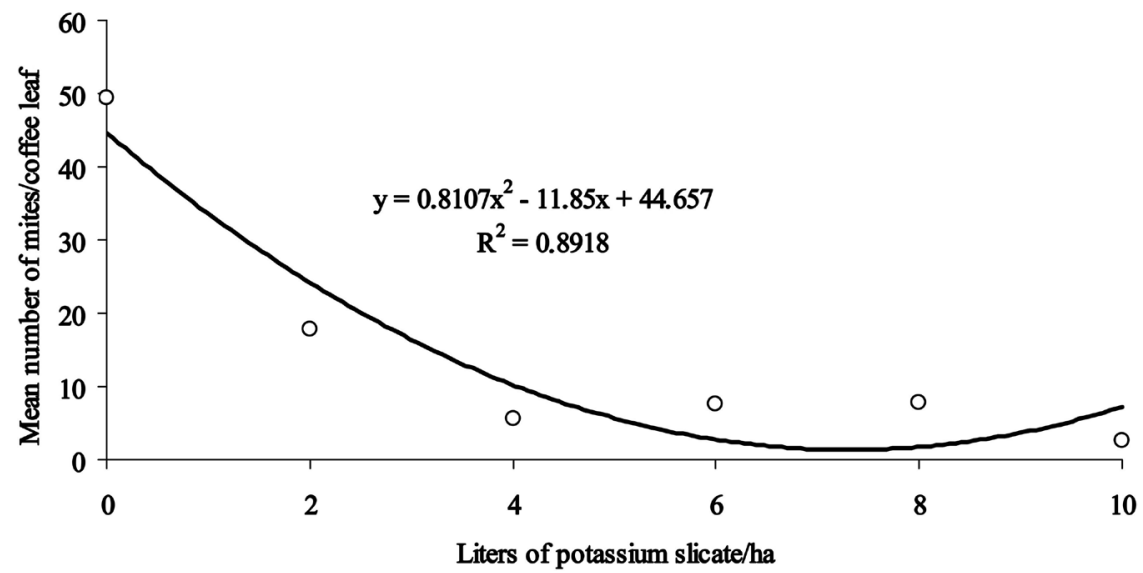

Figure 1. Mean number of Oligonychus ilicis mites (adults, larvae and alive nymphs) per coffee leaf, as a function of the topical plus residual effect, at 15 days after the second application, according to the different doses of applied potassium silicate (Markers $=$ observed number; Line $=$ estimated number) $\left(\mathrm{Lab}\right.$ temperature of $25^{\circ} \mathrm{C} \pm 2{ }^{\circ} \mathrm{C}, 70 \% \pm 10 \%$ $\mathrm{RH}$ and $14 \mathrm{~h}$ of photophase).

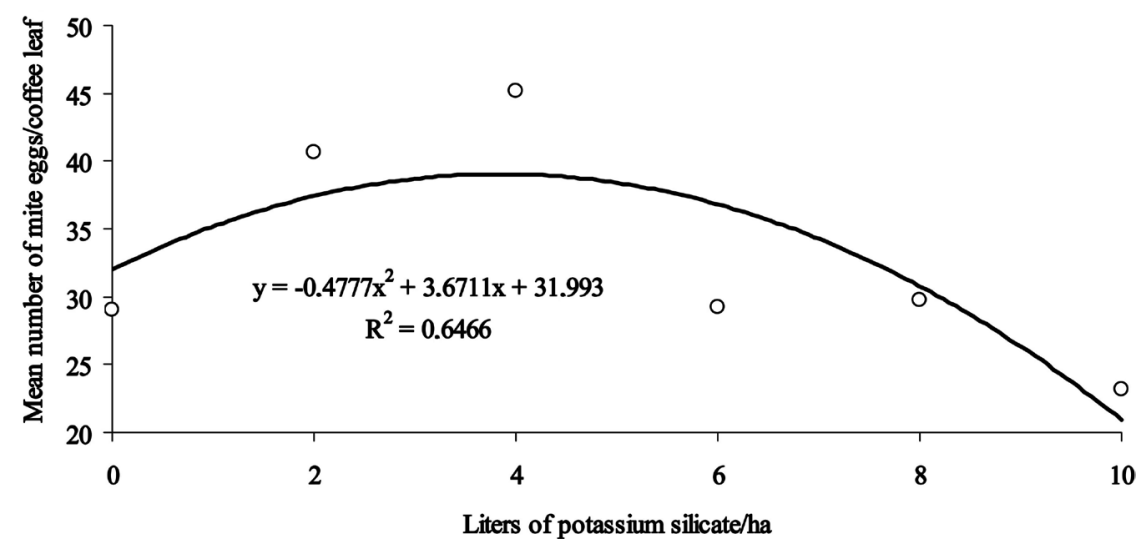

Figure 2. Mean number of Oligonychus ilicis eggs per coffee leaf, as a function of the topical plus residual effect, at 15 days after the second application, according to the different doses of applied potassium silicate (Markers $=$ observed number; Line $=$ estimated number) (Lab temperature of $25^{\circ} \mathrm{C} \pm 2{ }^{\circ} \mathrm{C}, 70 \% \pm 10 \% \mathrm{RH}$ and $14 \mathrm{~h}$ of photophase). 
Table 3. Number (mean \pm SE) of alive mites (adults, larvae and nymphs) of Oligonychus ilicis, per coffee leaf, as a function of the residual effect of potassium silicate, after 3, 7 and 21 days after the leaf spraying.

\begin{tabular}{lccc}
\hline $\begin{array}{c}\text { Treatments } \\
\text { Liters of potassium } \\
\text { silicate/ha }\end{array}$ & $\begin{array}{c}\text { At } 3 \text { days after the } \\
\text { application }\end{array}$ & $\begin{array}{c}\text { At } 7 \text { days after the } \\
\text { application }\end{array}$ & $\begin{array}{c}\text { At } 21 \text { days after the } \\
\text { application }\end{array}$ \\
\hline $\begin{array}{c}\text { 1. Control } \\
\text { 2. } 2 \text { liters }\end{array}$ & $19.60 \pm 09.26 \mathrm{a}$ & $44.60 \pm 13.01 \mathrm{a}$ & $50.00 \pm 00.00 \mathrm{a}$ \\
3. 4 liters & $04.60 \pm 10.28 \mathrm{~b}$ & $08.80 \pm 14.17 \mathrm{~b}$ & $06.80 \pm 01.09 \mathrm{~b}$ \\
4. 6 liters & $00.40 \pm 00.89 \mathrm{~b}$ & $09.00 \pm 13.47 \mathrm{~b}$ & $02.00 \pm 00.00 \mathrm{~cd}$ \\
5.8 liters & $02.20 \pm 04.92 \mathrm{~b}$ & $07.00 \pm 06.70 \mathrm{~b}$ & $00.20 \pm 00.45 \mathrm{~d}$ \\
6.10 liters & $00.00 \pm 00.00 \mathrm{~b}$ & $03.80 \pm 06.94 \mathrm{~b}$ & $03.40 \pm 02.07 \mathrm{~cd}$ \\
\hline
\end{tabular}

${ }^{\star}$ Means followed by the same letter in the column do not differ by Tukey's test $(\mathrm{P} \leq 0.05)$.

Table 4. Number (mean \pm SE) of Oligonychus ilicis eggs per coffee leaf, as a function of the residual effect of potassium silicate, after 3, 7 and 21 days after the leaf spraying.

\begin{tabular}{lccc}
\hline $\begin{array}{c}\text { Treatments } \\
\text { Liters of potassium } \\
\text { silicate/ha }\end{array}$ & $\begin{array}{c}\text { At } 3 \text { days after the } \\
\text { application }\end{array}$ & $\begin{array}{c}\text { At } 7 \text { days after the } \\
\text { application }\end{array}$ & $\begin{array}{c}\text { At } 21 \text { days after the } \\
\text { application }\end{array}$ \\
\hline 1. Control & $101.60 \pm 64.88 \mathrm{a}$ & $45.20 \pm 1.64 \mathrm{a}$ & $50.80 \pm 1.30 \mathrm{a}$ \\
2. 2 liters & $021.80 \pm 13.10 \mathrm{~b}$ & $09.80 \pm 9.40 \mathrm{~b}$ & $02.00 \pm 0.71 \mathrm{~b}$ \\
3. 4 liters & $001.00 \pm 02.24 \mathrm{~b}$ & $02.80 \pm 4.38 \mathrm{~b}$ & $01.00 \pm 0.00 \mathrm{bc}$ \\
4. 6 liters & $000.60 \pm 01.34 \mathrm{~b}$ & $04.00 \pm 5.48 \mathrm{~b}$ & $00.00 \pm 0.00 \mathrm{c}$ \\
5.8 liters & $002.80 \pm 04.38 \mathrm{~b}$ & $05.20 \pm 5.97 \mathrm{~b}$ & $01.00 \pm 0.00 \mathrm{bc}$ \\
6. 10 liters & $000.00 \pm 13.10 \mathrm{~b}$ & $00.00 \pm 0.00 \mathrm{~b}$ & $00.00 \pm 0.00 \mathrm{c}$ \\
\hline
\end{tabular}

${ }^{*}$ Means followed by the same letter in the column do not differ by Tukey's test $(\mathrm{P} \leq 0.05)$.

In all evaluations the number of the pest mite eggs, was highest in the control (without application of potassium silicate - dose 0) compared to the other doses analyzed (Table 4).

\subsection{Si Content in Coffee Leaves after the Leaf Spraying}

All treatments had higher Si content in the leaves compared to the control, and the doses of 10 and 8 liters/ha of potassium silicate presented 18.4, 15 times more Si than the control, or $80 \%$ and $70 \%$ more Si, respectively (Figure 3).

\subsection{Index of Coffee Leaf Damage by the Mite Oligonychus ilicis in Greenhouse}

The results showed that the higher the dose, the lower was the damage caused by the southern red mite in the coffee leaves (reddish brown marks on the upper surface of the coffee leaves), a parameter measured by the damage index (score from 0 to 5). The control had the highest leaf area damage index (4.8) and 


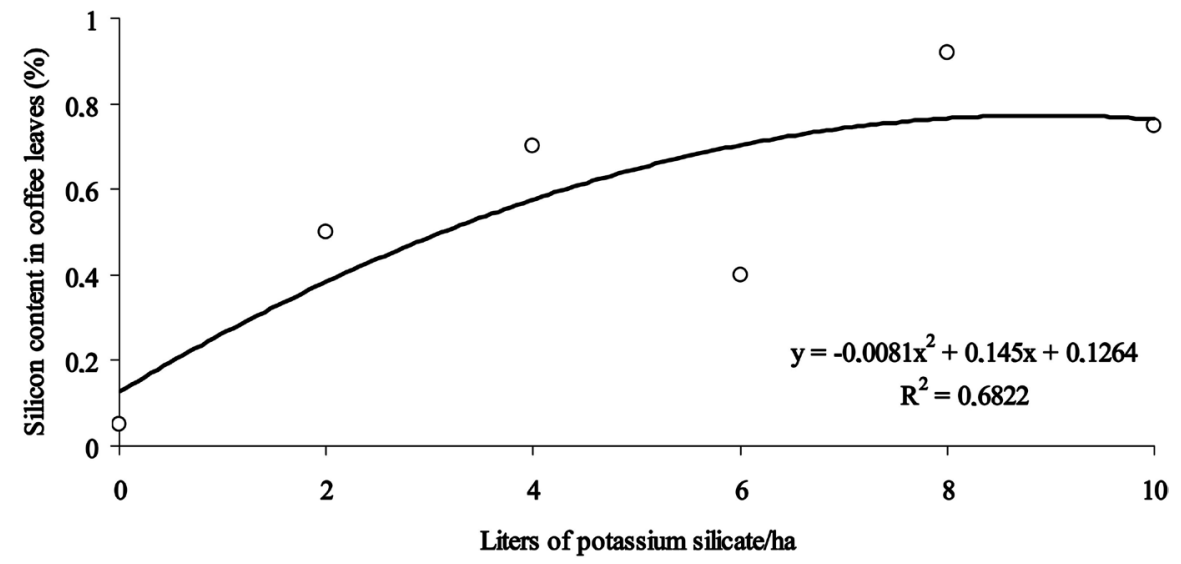

Figure 3. Silicon content (\%) in coffee leaves submitted to different concentrations of potassium silicate.

Table 5. Damage caused by Oligonychus ilicis on coffee leaf as a function of the potassium silicate dose applied and measured by the damage index (ID \pm SE).

\begin{tabular}{cc}
\hline Treatments Liters of potassium silicate/ha & Damage index $(\mathrm{ID} \pm \mathrm{SE})^{*}$ \\
\hline 1. Control & $4.8 \pm 0.45 \mathrm{a}$ \\
2.2 liters & $3.0 \pm 0.00 \mathrm{~b}$ \\
3.4 liters & $3.0 \pm 0.45 \mathrm{~b}$ \\
4.6 liters & $2.2 \pm 0.45 \mathrm{~b}$ \\
5.8 liters & $2.2 \pm 0.45 \mathrm{~b}$ \\
6. 10 liters & $1.2 \pm 0.45 \mathrm{c}$ \\
\hline
\end{tabular}

${ }^{*}$ Index of leaf mite damage, plus or minus standard error of the mean, according to Smith-Meyer [18]: $0=$ absence of damage; $1=$ up to $20 \%$ of the leaf area with damage; $2=21 \%-40 \%$ of leaf area with damage; $3=$ $41 \%$ - $60 \%$ of leaf area with damage; $4=61 \%-80 \%$ of leaf area with damage and $5=$ more than $80 \%$ of leaf area with damage. The mean values of damage index followed by the same letter in the column did not differ by Dunn's test $(\mathrm{p}=0.05)$.

Table 6. Tannins and lignin contents (mean \pm SE) in coffee leaves without and with potassium silicate applied by leaf spraying.

\begin{tabular}{ccc}
\hline Treatments & Tannins $(\%)^{*}$ & Lignin (\%)* \\
\hline Without Si (control) & $22.60 \pm 0.31 \mathrm{~b}$ & $8.53 \pm 0.30 \mathrm{~b}$ \\
With Si (10 liters/ha) & $24.42 \pm 0.24 \mathrm{a}$ & $9.40 \pm 0.53 \mathrm{a}$ \\
\hline
\end{tabular}

${ }^{*}$ Means followed by the same letter in the column do not differ by Tukey's test $(\mathrm{P} \leq 0.05)$.

treatment 6, 10 liters of potassium silicate/ha, the lowest (1.2) (Table 5).

\subsection{Tannins and Lignin Contents in Coffee Leaves after Leaf Spraying}

The leaves of the coffee trees sprayed with potassium silicate, represented by the highest applied dose, 10 liters/ha, presented a higher percentage of tannins and lignin than the plants without Si (control treatment) (Table 6).

\section{Discussion}

Potassium silicate in leaf spraying, at all doses analyzed, provided a reduction of 
$O$. ilicis mite infestation in coffee plants, similar to that already verified by other authors and other pests; for example, silicon application negatively affected the number of nymphs and the growth of the $S$. graminum aphid population in rice plants [23] [24].

In this study it was observed that protective effect of silicon can be associated with chemical and physical changes of the plant, such as hardening of the leaf tissue, causing a reduction in the pest mite feeding and in the mite population (immatures, adults and eggs), consequently reduction of the damage caused in leafs coffee plants.

It has also been observed that there was the induction of plant defense compounds such as tannins and lignin. The increase of lignin in leaf tissues of coffee plants fertilized with sodium or calcium silicate has already been reported [25], but no increase in lignin content was observed with the application of silicon in the soybean [Glycine $\max$ (L.) Merril, Fabaceae] [26]. The secondary metabolites produced by the plants can be toxics or deterrents of feeding to the herbivores, causing nutritional limitation [27]. The most important group of secondary defensive compounds is tannins, since they act as food deterrents [28]. The synthesis and accumulation of tannins in coffee leaves may have contributed to the induction of coffee resistance to the $O$. ilicis mite in this work. Lignin is a complex polymer that when deposited on the cell wall is responsible for its hardness and increased resistance to attack by external agents [29], thus causing a mechanical barrier, making the cell wall more resistant.

It has also been reported that the resistance conferred by the leaf silicon application causes chemical and physical changes in three varieties of Poaceae (Deschampsia caespitosa L, Festuca ovina and Lolium perene L.) such as reduced digestibility, increased tissue stiffness and increased abrasiveness [30]. However, with application of calcium silicate in the soil, it was already observed in coffee that the mealybug, $P$. citri, reached the phloem feeding place without problems, indicating that in this study, no mechanical barrier was performed to avoid the penetration of the buccal stylets [31].

Evidence for feeding deterrence to herbivorous arthropods in maize plants $(Z$. mays) were observed to the fall armyworm, Spodoptera frugiperda Smith \& Abbot (Lepidoptera: Noctuidae), with inhibition of feeding in plants treated with sodium silicate, where the caterpillars presented wear out of the jaws on the incisor region when in contact with leaves with higher silicon content, high mortality and cannibalism due to the increase of resistance to this species [32]. Applications of calcium silicate in sugarcane (Saccharum officinarum L., Poaceae) were also correlated with the reduction of damage caused by Eldana saccharina Walker (Lepidoptera: Pyralidae) [33] [34].

In corn, bean, cucumber and eggplant the application of potassium silicate increased the resistance of these plants against the two-spotted spider mite, $T$. urticae, infestation, causing reduction of their feeding [13]. Also in common bean, $P$. vulgaris, it was verified that the duration of developmental stage of $T$. urticae was significantly affected by Si doses. The longest immature period, the shortest longevity of females and the shortest oviposition period were obtained 
with $2 \mathrm{ppm}$ of $\mathrm{Si}$, affected population growth parameters and a better potential for decreasing the population of this mite. So the application of $S i$ in this case can be used in the mite integrated pest management programs [35].

In the present study were observed a reduction the number of eggs laid by $O$. ilicis in the coffee leaves sprayed with $\mathrm{Si}$, probably due the mite feeding difficulty that caused a reduction of the fecundity of the population. For the aphid, $S$. graminum, it has been demonstrated that the application of Si reduces its fecundity, preference and longevity in rice leaves (Oyza sativa L, Poaceae), treated with sodium silicate [36].

The application by leaf spraying of different doses of potassium silicate allow to demonstrate that the concentration of $\mathrm{Si}$ in the coffee leaves increased according to the increase of the applied dose, indicating that there was absorption by the plant, even though the coffee tree was a dicotyledonous plant. A similar result was observed also in coffee plants in other studies [37]. In results obtained with leaf application of $\mathrm{Si}$ in potato plants (Solanum tuberosum L., Solanaceae), it was observed that silicon acts as a resistance inducer to aphids Myzus persicae (Sulzer) (Hemiptera: Aphididae) [24], despite these plants being classified as non-accumulators of this mineral [38].

In the present study no significant difference was observed in the infestation of coffee plants with $O$. ilicis in relation to the different doses of Si used in leaf spraying. Also, no difference was observed in the number of eggs and in the development time of the mealybug Planococcus citri (Risso) (Hemiptera: Pseudococcidae) with the increase of Si rates in citrus (Citrus spp., Rutaceae) [39], which indicates the importance of the application of Si.

Concerning the damage avoided with the use of $\mathrm{Si}$ in leaf spraying, it has already been found that Diabrotica speciosa (Germar) (Coleoptera: Chrysomelidae) causes twice as many lesions in the control as in plants of potato ( $S$. tuberosum) treated with silicic acid [40]. It has also been found that the application of potassium silicate in cocoa plants (Theobroma cacao L., Malvaceae) reduced the incidence and level of damage caused by insect pests [41].

In the development of this work, the application of potassium silicate increased resistance to damage caused by the mite $O$. ilicis, which was confirmed by the decrease in the value of the damage index found when $\mathrm{Si}$ was applied in leaf spraying.

The applications of potassium silicate as a source of silicon ( $\mathrm{Si}$ ) result in a positive effect in reducing the population of $O$. ilicis mites and in the damage caused by it in coffee leaves, even if it is a dicotyledonous plant. Therefore, the applications of potassium silicate by leaf spraying can be used in programs of integrated management of the southern red mite in coffee plants, with a view to sustainable management and environmental protection.

\section{Acknowledgements}

To the Conselho Nacional de Desenvolvimento Científico e Tecnológico - National Council for Scientific and Technological Development - CNPq and Coor- 
denação de Aperfeiçoamento de Pessoal de Nível Superior - Coordination of Improvement of Higher Level Personnel - CAPES, for financial support and fellowships granted.

\section{References}

[1] Moraes, G.J. and Flechtmann, C.H.W. (2008) Manual de Acarologia, Holos, Ribeirão Preto, $288 \mathrm{p}$.

[2] Franco, R.A., Reis, P.R., Zacarias, M.S. and Oliveira, D.C. (2009) Influência da infestação de Oligonychus ilicis (McGregor, 1917) (Acari: Tetranychidae) sobre a taxa de fotossíntese potencial de folhas de cafeeiro. Arquivos do Instituto Biológico, 76, 205-210.

[3] Reis, P.R. and Zacarias, M.S. (2007) Ácaros em cafeeiro. EPAMIG, Belo Horizonte, 76 p. (EPAMIG. Boletim Técnico, 81). http://www.epamig.br/download/bt81-acaros-em-cafeeiro/

[4] Reis, P.R. and Souza, J.C. (1996) Pragas do cafeeiro. In: Rena, A.B. Malavolta, E., Rocha, M. and Yamada, T., Eds., Cultura do cafeeiro: Fatores que afetam a produtividade. POTAFOS, Piracicaba, 323-378.

[5] Butt, T.M., Jackson, C. and Magan, N. (2001) Introduction-Fungal Biological Control Agent: Progress, Problems and Potential, In: Butt, T.M., Jackson, C. and Magan, N., Eds., Fungi as Biological Control Agents. Progress, Problems and Potential, CABI Publishing, Wallingford (UK), 1-8. https://doi.org/10.1079/9780851993560.0001

[6] Stumpf, N. and Nauen, R. (2001) Cross-Resistance, Inheritance and Biochemistry of Mitochondrial Electron Transport Inhibitor-Acaricide Resistance in Tetranychus urticae (Acari: Tetranychidae). Journal Economic Entomology, 94, 1577-1583. https://doi.org/10.1603/0022-0493-94.6.1577

[7] Nicastro, R.L., Sato, E.M. and Silva, M.Z. (2010) Milbemectin Resistance in Tetranychus urticae (Acari: Tetranychidae) Selection, Stability and Cross-Resistance to Abamectin. Experimental and Applied Acarology, 50.

[8] Korndörfer, G.H., Pereira, H.S. and Camargo, M.S. (2004) Silicatos de cálcio e magnésio na agricultura. Uberlândia: UFU, GPSi, ICIAG. 24 p. (GPSi-ICIAG-UFU. Boletim Técnico, 1).

[9] Savant, N.K., Snyder, G.H. and Datnoff, L.E. (1996) Silicon Management and Sustainable Rice Production. Advance in Agronomy, 58, 151-199.

https://doi.org/10.1016/S0065-2113(08)60255-2

[10] Laing, M.D., Gatarayiha, M.C. and Adandonon, A. (2006) Silicon Use for Pest Control in Agriculture: A Review. Proceedings of the South African Sugar Technologists Association, 80, 278-286. https://www.researchgate.net/publication/228760373

[11] Keeping, M.G. and Kvederas, O.L. (2008) Silicon as a Plant Defense against Insect Herbivory: Response to Massey, Ennos and Hartley. Journal of Animal Ecology, 77, 631-633. https://doi.org/10.1111/j.1365-2656.2008.01380.x

[12] Costa, R.R., Moraes, J.C. and Da Costa, R.R. (2011) Feeding Behaviour of the Greenbug Schizaphis graminum on Wheat Plants Treated with Imidacloprid and/or Silicon. Journal Applied Entomology, 135, 115-120. https://doi.org/10.1111/j.1439-0418.2010.01526.x

[13] Gatarayiha, M.C., Laing, M.D. and Miller, R.M. (2010) Combining Applications of Potassium Silicate and Beauveria bassiana to Four Crops to Control Two Spotted Spider Mite, Tetranychus urticae. International Journal of Pest Management, 56, 
291-297. https://doi.org/10.1080/09670874.2010.495794

[14] Assis, F.A., Moraes, J.C., Auad, A.M. and Coelho, M. (2013) The Effects of Foliar Spray Application of Silicon on Plant Damage Levels and Components of Larval Biology of the Pest Butterfly Chlosyne lacinia saundersii (Nymphalidae). International Journal of Pest Management, 28, 128-134. https://doi.org/10.1080/09670874.2013.779049

[15] Kvedaras, O.L., An, M., Choi, Y.S. and Gurr, G.M. (2010) Silicon Enhances Natural Enemy Attraction and Biological Control through Induced Plant Defenses. Bulletin of Entomology Research, 100, 367-371. https://doi.org/10.1017/S0007485309990265

[16] McMurtry, J.A. and Scriven, G.T. (1965) Insectary Production of Phytoseiid Mites. Journal of Economic Entomology, 58, 282-284. https://doi.org/10.1093/jee/58.2.282

[17] Reis, P.R., Alves, E.B. and Sousa, E.O. (1997) Biologia do ácaro-vermelho do cafeeiro Oligonychus ilicis (McGregor, 1917). Ciência e Agrotecnologia, 21, 260-266.

[18] Smith-Meyer, M.K.P. (1996) Mite Pests and Their Predators on Cultivated Plants in Southern Africa: Vegetables and Berries. ARC-Plant Protection Research Institute Handbook No. 6 (South Africa), Pretoria, 90 p.

[19] Deshpande, S.S., Cheryan, M. and Salunke, D.K. (1986) Tannin Analysis of Food Products. Critical Review in Food Science and Nutrition, 24, 401-449. https://doi.org/10.1080/10408398609527441

[20] AOAC International (2016) Official Methods of Analysis of the Association of AOAC International. $20^{\text {th }}$ Edition, AOAC International, Rockville, MD.

[21] Van Soest, P.J. (1967) Development of a Comprehensive System of Feed Analysis and Its Applications to Forage. Journal of Animal Science, 26, 119-128. https://doi.org/10.2527/jas1967.261119x

[22] Sigma Plot for Windows, Version 9.01 (2004) Systat Software, Inc., Chicago, IL.

[23] Costa, R.R. and Moraes, J.C. (2006) Efeitos do ácido silícico e do acibenzolar-s-methyl sobre Schizaphis graminum (Rondani) (Hemiptera: Aphididae) em plantas de trigo. Neotropical Entomology, 35, 834-839. http://dx.doi.org/10.1590/S1519-566X2006000600018

[24] Gomes, F.B., Moraes, J.C., Santos, C.D. and Antunes, C.S. (2008) Uso de silício como indutor de resistência em batata a Myzus persicae (Sulzer) (Hemiptera: Aphididae). Neotropical Entomology, 37, 185-190. http://dx.doi.org/10.1590/S1519-566X2008000200013

[25] Botelho, D.M.S., Pozza, E.A., Pozza, A.A.A., Carvalho, J.G., Botelho, C.E. and Souza, P.E. (2005) Intensidade da cercosporiose em mudas de cafeeiro em função de fontes e doses de silício. Fitopatologia Brasileira, 30, 582-588. http://dx.doi.org/10.1590/S0100-41582005000600003

[26] Ferreira, R.S., Moraes, J.C. And Antunes, C.S. (2011) Silicon Influence on Resistance Induction against Bemisia tabaci Biotype B (Genn.) (Hemiptera: Aleyrodidae) and on Vegetative Development in Two Soybean Cultivars. Neotropical Entomology, 40, 495-500. http://dx.doi.org/10.1590/S1519-566X2011000400014

[27] Bialcyk, J., Lechowski, Z. and Libik, A. (1999) The Protective Action of Tannins against Glasshouse Whitefly in Tomato Seedlings. Journal of Agricultural Science, 133, 197-201. https://doi.org/10.1017/S0021859699006607

[28] Swain, T. (1977) Secondary Compounds as Protective Agents. Annual Review of Plant Physiology, 28, 479-501. https://doi.org/10.1146/annurev.pp.28.060177.002403

[29] Strack, D. (1997) Phenolic Metabolism. In: Dey, J.B. and Harbone, J.B., Eds., Plant 
Biochemistry, Academic Press, London, 554 p.

[30] Massey, E.P. and Hartley, S.E. (2009) Physical Defense Wear You Down: Progressive and Irreversible Impacts of Silica on Insect Herbivores. Journal of Animal Ecology, 78, 281-291. http://dx.doi.org/10.1111/j.1365-2656.2008.01472.x

[31] Santa-Cecília, L.V.C., Prado, E. and Moraes, J.C. (2014) Avaliação do silício no comportamento alimentar da cochonilha branca Planococcus citri (Risso) (Pseudococcidae) em cafeeiro. Coffee Science, 9, 10-13.

http://www.sbicafe.ufv.br/handle/123456789/8011

[32] Goussain, M.M., Moraes, J.C., Carvalho, J.G., Nogueira, N.L. and Rossi, M.L. (2002) Efeito da aplicação de silício em plantas de milho no desenvolvimento biológico da lagarta do cartucho Spodoptera frugiperda (J.E. Smith) (Lepidoptera: Noctuidae). Neotropical Entomology, 31, 305-310. http://dx.doi.org/10.1590/S1519-566X2002000200019

[33] Keeping, M.G. and Meyer, J.H. (2002) Calcium Silicate Enhances Resistance of Sugarcane to the African Stalkborer, Eldana saccharina Walker (Lepidoptera: Pyralidae). Agricultural and Forest Entomology, 4, 265-274. http://dx.doi.org/10.1046/j.1461-9563.2002.00150.x

[34] Kvedaras, O.L. and Keeping, M.G. (2007) Silicon Impedes Stalk Penetration by the borer Eldana saccharina in Sugarcane. Entomologia Experimentalis et Applicata, 125, 103-110. http://dx.doi.org/10.1111/j.1570-7458.2007.00604.x

[35] Sadeghi, E., Shoushtari, R.S. and Madani, H. (2016) The Influence of Tetranychus urticae Koch (Acari: Tetranychidae) Life Table and Reproductive Parameters by Applying Si on Bean at Library Condition. Advances in Entomology, 4, 260-267. http://dx.doi.org/10.4236/ae.2016.45027

[36] Moraes, J.C., Goussain, M.M., Carvalho, G.A. and Costa, R.R. (2005) Feeding Non-Preference of the Corn Leaf Aphid Rhopalosiphum maidis (Fitch, 1856) (Hemiptera: Aphididae) to Corn Plants (Zea mays L.) Treated with Silicon. Ciência e Agrotecnologia, 29, 761-766. http://dx.doi.org/10.1590/S1413-70542005000400007

[37] Fernandes, A.L.T., Merrighi, A.L.N., Silva, G.A. and Fraga Júnior, E.F.F. (2009) Utilização do silício no controle de pragas e doenças do cafeeiro irrigado. FAZU em Revista, 6, 11-52.

[38] Ma, J.F., Miyake, Y. and Takahashi, E. (2001) Silicon as a Beneficial Element for Crop Plants. In: Dafnoff, L.E., Snyder, G.H. and Korndörfer, G.H., Eds., Silicon in Agriculture, Elsevier Science B.V., the Netherlands, 403 p. https://doi.org/10.1016/S0928-3420(01)80006-9

[39] Hogendorp, B.K., Cloyd, R.A. and Swiader, J.M. (2009) Effect of Silicon-Based Fertilizer Applications on the Reproduction and Development of the Citrus Mealybug (Hemiptera: Pseudococcidae) Feeding on Green Coleus. Journal of Economic Entomology, 102, 2198-2209. https://doi.org/10.1603/029.102.0624

[40] Gomes, F.B, Moraes, J.C. and Neri, D.K.P. (2009) Adubação com silício como fator de resistência a insetos praga e promotor de produtividade em cultura de batata inglesa em sistema orgânico. Ciência e Agrotecnologia, 33, 18-23.

http://dx.doi.org/10.1590/S1413-70542009000100002

[41] Pinto, D.G., Aguilar, M.A.G., Souza, C.A.S., Silva, D.M., Siqueira, P.R. and Cao, J.R. (2014) Fotossíntese, crescimento e incidência de insetos-pragas em genótipos de cacau pulverizados com silício. Bioscience Journal, 30, 715-724.

http://www.seer.ufu.br/index.php/biosciencejournal/article/view/18097 